Available online at GSC Online Press Directory

GSC Biological and Pharmaceutical Sciences

e-ISSN: 2581-3250, CODEN (USA): GBPSC2

Journal homepage: https://www.gsconlinepress.com/journals/gscbps

(RESEARCH ARTICLE)

\title{
Antimicrobial screening of the crude extract of Hannoa klaineana against some pathogens
}

Ibe Chioma Ifeoma ${ }^{1}$, Ajaegbu Eze Elijah ${ }^{2,}{ }^{*}$, Ikuesan Adeniran John ${ }^{2}$, Dieke Adaobi Janefrances ${ }^{2}$ and Ezugwu Obidike Christopher ${ }^{3}$

${ }^{1}$ Department of Pharmacognosy and Traditional Medicine, Faculty of Pharmaceutical Sciences, Nnamdi Azikiwe University, Awka, Anambra State, Nigeria.

${ }^{2}$ Department of Applied Sciences, Faculty of Applied Sciences and General Studies, Federal College of Dental Technology and Therapy, Trans-Ekulu, Enugu State, Nigeria.

${ }^{3}$ Department of Pharmacognosy and Environmental Medicine, Faculty of Pharmaceutical Sciences, University of Nigeria, Nsukka, Enugu State, Nigeria.

Publication history: Received on 20 July 2020; revised on 29 July 2020; accepted on 30 July 2020

Article DOI: https://doi.org/10.30574/gscbps.2020.12.1.0233

\begin{abstract}
Hannoa klaineana is an ever green plant belonging to the Simaroubaceae family commonly known as Oghuru in Igbo, itekiri in Edo and igi gun in Yoruba. It has been used in ethnomedicine for the treatment of malaria, cough, and stomach problems. The present study assessed the antimicrobial property of the extract of $H$. klaineana against Staphylococcus aureus, Salmonella typhi, Escherichia coli, Pseudomonas aeruginosa, Bacilus substilus, and Candida albicans using the agar diffusion method. Our preliminary phytochemical studies showed the presence of resins, steroids, terpenoids, glycosides, alkaloids, flavonoids, tannins, saponins, and phenols. Quantitative determination of the phytochemicals present revealed alkaloids (1.2\%), tannins (11.2\%), flavonoids (3\%), saponins (29.3\%), and phenolic compounds $(45.7 \%)$. The extract of $\mathrm{H}$. klaineana showed good antimicrobial activity against $C$. albicans and moderate active against S. aureus, S. typhi, E. coli, P. aeruginosa, B. substilus. These results further confirm the potentials of Nigerian plants as a source of bioactive compounds with pharmaceutical, agricultural or industrial applications.
\end{abstract}

Keywords: Antimicrobial; Phytochemical; Bacteria; Fungi; Hannoa klaineana.

\section{Introduction}

Medicinal plants are described by the World Health Organization (WHO) as plants that hold within compounds that can be utilized for therapeutic purposes or can be combined to create very able drugs [1]. Natural products are compounds created by microorganisms e.g. bacteria, fungi, etc., and plants to respond to changes. They are greatly utilized in industries e.g. pharmaceuticals, etc., for a range of pharmacological activities and striking structural diversity [2]. The rise in the population of the world, disease, health problems, etc. is of great concern. These have led to the use of these chemical molecules or compounds from these plants as pharmaceutical agents.

Phytochemicals are bioactive compounds found in plant diets such as fruits, vegetables, grains, beans that are responsible for disease protection [3]. Hannoa klaineana has been used several in ethnomedicine to treat cough, malaria, stomach problems. Some studies have proven its antimicrobial, anti-inflammatory, antiviral activity, anti feedant, and anti-tumor activities. It is the most known in Nigeria, among the other species of Simaroubaceae [4]. It is used in other African countries to take care of fevers, malaria, cough, colic diseases, and antitumor activity [5]. The general objective

\footnotetext{
* Corresponding author: Ajaegbu Eze Elijah
} 
Ibe et al. / GSC Biological and Pharmaceutical Sciences, 2020, 12(01), 249-254

of this study was to evaluate the potential activity of the extract and fractions of the stem bark of $H$. klaineana on bacteria and to validate the medicinal values of the plant extract.

\section{Material and methods}

\subsection{Plant collection and extraction}

The stem bark of the plant was brought together from Orba, Nsukka, Enugu State Nigeria, and impurities were removed, air-dried in the Pharmacognosy laboratory.

The extraction and fractionation process was carried out according to the method by [6]. It was pulverized into a powder and extracted in methanol with shaking for 48 hours. The filtrates were collected and concentrated to dryness with a rotary evaporator at $40^{\circ} \mathrm{C}$. The crude methanol extract of $H$. klaineana was first absorbed on silica gel and sequentially extracted using n-hexane, chloroform, ethylacetate, methanol in increasing order of polarity. The fractions so obtained were filtered twice using Whatman no 1 filter paper. A rotary evaporator was used to concentrate the fractions at $45^{\circ} \pm 5^{\circ} \mathrm{C}$. The extract and fractions obtained were stored at $4^{\circ} \mathrm{O}$. The extracts of the plant were analyzed for the antimicrobial property.

\subsection{Qualitative Phytochemical Screening}

Phytochemical screening tests were carried out on the powdered stem bark and crude extract to determine phytochemical constituents using methods described by [7].

\subsection{Quantitative phytochemical analysis}

The coarse powder of the plant material was tested for quantitative estimation to determine the number of alkaloids, flavonoids, phenols, saponins, and tannins present.

\subsubsection{Determination of total phenols by spectrophotometric method}

$5 \mathrm{~g}$ of sample was boiled with $50 \mathrm{ml}$ of ether for the extraction of the phenolic component for $15 \mathrm{mins} .5 \mathrm{ml}$ of the extract was placed in $50 \mathrm{ml}$ flask, and then $10 \mathrm{ml}$ of distilled water was added. $2 \mathrm{ml}$ of ammonium hydroxide solution and $5 \mathrm{ml}$ of concentrated amyl alcohol were also added. The samples were left to react for 30 mins for colour development [8]. This was measured at $505 \mathrm{~nm}$. The standard curve was prepared using 0, 50, 100, 150, 200,250 mg/L solutions of gallic acid in methanol: water $(50: 50 \mathrm{v} / \mathrm{v})$.

\subsubsection{Alkaloid determination}

$5 \mathrm{~g}$ of the sample of powdered bark was weighed into a $250 \mathrm{ml}$ beaker and $200 \mathrm{ml}$ of $10 \%$ acetic acid in ethanol was added and allowed to stand for $4 \mathrm{hrs}$. This was filtered and the extract was concentrated on a water bath to one-quarter of the original volume. Concentrated ammonium hydroxide was added drop-wise to the extract until the precipitation ceases. The precipitate was collected and washed with dilute ammonium hydroxide and then filtered, the residue is the alkaloid, which was dried and weighed [9].

\subsubsection{Flavonoid determination}

$10 \mathrm{~g}$ of the plant sample was extracted repeatedly with $100 \mathrm{ml}$ of $80 \%$ aqueous methanol at room temperature. The whole solution was filtered through Whatman filter paper. The filtrate was later transferred into a crucible and evaporated into dryness over a water bath and weighed to a constant weight [10].

\subsubsection{Saponin determination}

This was done according to the method by Obdoni and Ochuko [11]. $20 \mathrm{~g}$ of sample powder in a conical flask was added $100 \mathrm{ml}$ of $20 \%$ aqueous ethanol. The samples were heated over a hot water bath for $4 \mathrm{hrs}$ with continuous stirring at about $55^{\circ} \mathrm{C}$. The mixture was filtered and the residue re-extracted with another $200 \mathrm{ml}$ of $20 \%$ aqueous ethanol. The combined extracts were reduced to $40 \mathrm{ml}$ over a water bath at about $90^{\circ} \mathrm{C}$. The concentrated was transferred into a 250 $\mathrm{ml}$ separating funnel and $20 \mathrm{ml}$ diethyl ether was added and shaken vigorously. The aqueous layer was recovered while the ether layer was discarded. The purification process was repeated with $60 \mathrm{ml}$ of $\mathrm{n}$-butanol. The combined n-butanol was washed twice with $10 \mathrm{ml}$ of $5 \%$ aqueous sodium chloride. The remaining solution was heated in a water bath. After evaporation, the samples were dried in the oven to a constant weight and the saponin content was calculated as the percentage weight. 


\subsubsection{Determination of tannins content}

Dried plant material $(0.5 \mathrm{~g})$ was extracted with $300 \mathrm{ml}$ of ether for 20 hours at room temperature. The residue was boiled for $2 \mathrm{hrs}$ with $100 \mathrm{ml}$ of distilled water, and then allowed to cool and was filtered, the extract was adjusted to a volume of $100 \mathrm{ml}$ in a volumetric flask. The content of the tannins in the extract was determined colorimetrically using Foling-Denis reagent and by measuring the absorbance of the blue complex at $760 \mathrm{~nm}$ using the tannic acid solution as a standard solution [12].

\subsection{Antimicrobial Assay}

The antimicrobial susceptibility testing was carried out using the agar well diffusion technique [13]. The stock solution of the extract was prepared by dissolving $4 \mathrm{~g}$ of the extract in DMSO to get a final concentration of $400 \mathrm{mg} / \mathrm{ml} .0 .5 \mathrm{ml} \mathrm{of}$ the test bacterium and fungi isolates standardized to an inoculums concentration equivalent to $1 \times 10^{8} \mathrm{CFU}$ (Mac Farland 0.5 standard) were introduced using Finn Pipette and spread into Mollen mullen Hinton agar (for bacterial isolates) and Sabourard agar (for fungi isolates) plates to achieve a confluent growth. The plates were allowed to dry and sterile cork borer of $6 \mathrm{~mm}$ diameter was used to bore wells in the agar plates. $20 \mu \mathrm{l}$ of the various concentration of the plant extract $(400,200,100,50,25,12.5$, and $6.25 \mathrm{mg} / \mathrm{ml})$ were introduced into the wells. The plates were allowed to stand for 1 hour or more for diffusion to take place and then incubated at $37^{\circ} \mathrm{C}$ for $24 \mathrm{hrs}$. The zone of inhibition was recorded to the nearest millimeter; the MIC (minimum inhibitory concentration) of the extract that was able to produce a zone of inhibition on the test organisms. These analyses were performed in triplicate.

\section{Results}

The results were analyzed based on phytochemical parameters and antimicrobial activity obtained in the methanol crude extract. Preliminary qualitative phytochemical screening indicates the presence of alkaloids, glycosides, flavonoids, fats and oils, resins, steroids, terpenoids, tannins, acidic compounds, saponins, proteins, and starch. The quantitative estimation of phyto-constituents in the stem bark of $H$. klaineana is shown in Table 1 ; having phenols (45.7\%), saponins (29.3\%), and tannins (11.2\%) as the highest phytochemical components in the stem bark of this plant.

Table 1 Quantitative estimation of phyto-constituents in the stem bark of the plant

\begin{tabular}{ll}
\hline Constituent & Percentage $(\% \mathbf{w} / \mathbf{w})$ \\
\hline Alkaloids & $1.2 \pm 0.023$ \\
Tannins & $11.2 \pm 0.044$ \\
Flavonoids & $3.0 \pm 0.055$ \\
Saponins & $29.3 \pm 0.065$ \\
Total phenol & $45.7 \pm 0.074$ \\
\hline
\end{tabular}

The results of the antimicrobial activity are presented in Tables 2 and 3 . The methanol crude extract of the stem bark of H. klaineana has an inhibitory activity on all bacterial and fungal studied in this work. The inhibition zone diameter varied from $6.1 \mathrm{~mm}$ with $S$. aureus and P. aeruginosa to $4 \mathrm{~mm}$ with E. coli, S. Typhi, and B. substilis for bacterial tested with the highest concentration ( $400 \mathrm{mg} / \mathrm{ml}$ ). This plant has antifungal activity (Table 2). 
Table 2 Mean Inhibition Zone Diameter $(\mathrm{mm})$ produced by crude methanol extract of the Stem bark of H. klaineana on test organisms.

\begin{tabular}{|c|c|c|c|c|c|c|c|c|c|}
\hline \multirow{2}{*}{$\begin{array}{l}\text { Test } \\
\text { organisms }\end{array}$} & \multicolumn{7}{|c|}{ Concentration $(\mathrm{mg} / \mathrm{ml})$} & \multirow{2}{*}{$\begin{array}{l}\begin{array}{l}\text { Ciprofloxacin } \\
\text { (Positive } \\
\text { control) }\end{array} \\
10 \mu \mathrm{g} / \mathrm{ml}\end{array}$} & \multirow{2}{*}{$\begin{array}{l}\begin{array}{l}\text { Fluconazole } \\
\text { (Positive } \\
\text { control) }\end{array} \\
30 \mu \mathrm{g} / \mathrm{ml}\end{array}$} \\
\hline & 400 & 200 & 100 & 50 & 25 & 12.5 & 6.25 & & \\
\hline $\begin{array}{l}\text { Staphylococcus } \\
\text { Aureus }\end{array}$ & $6.1 \pm 0.1$ & $4.2 \pm 1.0$ & $2.3 \pm 0.3$ & - & - & - & - & $29.10 \pm 1.5$ & NA \\
\hline $\begin{array}{l}\text { Escherichia } \\
\text { coli }\end{array}$ & $4.3 \pm 0.3$ & $2.4 \pm 1.3$ & - & - & - & - & - & $28.2 \pm 0.7$ & NA \\
\hline $\begin{array}{l}\text { Pseudomonas } \\
\text { aeruginosa }\end{array}$ & $6.1 \pm 0.5$ & $4.0 \pm 0.1$ & $2.2 \pm 1.2$ & - & - & - & - & $21.5 \pm 0.5$ & NA \\
\hline $\begin{array}{l}\text { Salmonella } \\
\text { typhi }\end{array}$ & $4.2 \pm 1.0$ & $2.3 \pm 1.3$ & - & - & - & - & - & $28.0 \pm 0.5$ & NA \\
\hline $\begin{array}{l}\text { Bacillus } \\
\text { substilis }\end{array}$ & $4.0 \pm 1.2$ & $2.2 \pm 0.1$ & - & - & - & - & - & $24.3 \pm 1.2$ & NA \\
\hline $\begin{array}{l}\text { Candida } \\
\text { albicans }\end{array}$ & $10.2 \pm 1.0$ & $8.1 \pm 1.2$ & $6.3 \pm 1.5$ & $4.2 \pm 0.2$ & $2.2 \pm 0.1$ & $1.3 \pm 0.5$ & - & NA & $29.2 \pm 1.2$ \\
\hline
\end{tabular}

Key: - = (no activity), NA= not applicable, Cipro= Ciprofloxacin, Flu= Fluconazole

Table 3 Minimum inhibitory concentration (MIC) of crude methanol extract of the stem bark of H. klaineana on test organisms.

\begin{tabular}{ll}
\hline Test organisms & MIC $(\mathbf{m g} / \mathbf{m l})$ \\
\hline S.aureus & 50 \\
E.coli & 100 \\
PS. aeruginosa & 50 \\
S.typhi & 100 \\
B.substilis & 100 \\
C.albicans & 12.5 \\
\hline
\end{tabular}

\section{Discussion}

The results of this study showed that H. klaineana has biological activity. According to Odeghe et al. [14], who carried out a qualitative analysis on the selected medicinal plants (Achomanes difformis stem, Dioscorea bulbifera stem bark, Fadogia cienkowskii leaf, H. klaineana stem bark, and Vitex simplicifolia leaf); the study revealed the presence of essential phytochemicals such as alkaloid, glycoside, saponin, terpenoid, protein, carbohydrate, steroid, resin and flavonoid.

It was observed in the present study that the phytochemicals are present in these parts of the plant. The results of the phytochemicals analysis have shown the presence of alkaloids $(1.2 \%)$, tannins $(11.2 \%)$, flavonoids (3\%), saponins $(29.3 \%)$ and the highest percentage of phenolic compounds (45.7\%) (Table 1).

H. klaineana has antimicrobial activity. According to Danijela et al. [15], methanol and acetone extract of the leaf extracts of Ailanthus altissima (Simaroubaceae) has antibacterial and antifungal activity equivalent to standard antibiotics. The MIC of positive control gentamicin for antibacterial activity was $0.0 \mathrm{mg} / \mathrm{mL}$ in all cases, and positive control Bamphotericin for antifungal was $0.1 \mathrm{mg} / \mathrm{mL}$. With P. aeruginosa as an exception, the acetone extract showed a higher or similar activity to that of methanol: dichloromethane extract. The results for the extracts against different 
microorganisms varied from 0.0 to $0.6 \mathrm{mg} / \mathrm{mL}$. The study has presented that the acetone leaf extract had an excellent MIC of $0.04 \mathrm{mg} / \mathrm{mL}$ against E. coli. This value was as good as that of the generic drug gentamicin. This discrepancy with the results of other authors may be due to the extraction solvents or less sensitive bioassay methods used. The result against the fungus $C$. albicans was also very promising. The extracts had higher activity than amphotericin $\mathrm{B}$, a gold standard in antifungal therapy.

It was observed in the present study that the antimicrobial activity of $H$. klaineana extract is more effective against fungus $C$. albicans $(\mathrm{MIC}=12.5 \mathrm{mg} / \mathrm{ml}$ ), and moderately against some bacteria strains (E. coli (MIC $100 \mathrm{mg} / \mathrm{ml}), P$. Aeruginosa (MIC=50 mg/ml), S. aureus (MIC=50 mg/ml), S. typhi $(\mathrm{MIC}=100 \mathrm{mg} / \mathrm{ml})$, and B. substilis $(\mathrm{MIC}=100 \mathrm{mg} / \mathrm{ml})$ - Table 3. This antimicrobial activity can be attributed to the phytochemicals composition of this plant (alkaloids, saponins, tannins, flavonoids, etc. when compared with work done by Ajaiyeoba and Krebs [16] who worked on Quassia amara and Quassia undulate (Simaroubaceae). The extracts of the leaves and stem bark were effective against the six clinical strains and five fungi; the differences can be the different species used and/or differences in extraction and month of collection and even temperature.

\section{Conclusion}

From this study, it can be concluded that the antimicrobial screening of the crude extract of $H$. klaineana have very little effect on the anti-microbial activity, but showed more effect on the fungus, $C$. albicans. Further medicinal and toxicity tests can be carried out to show that the plant is safe for consumption as herbal medicine without plausible toxicity to body organs and tissues.

\section{Compliance with ethical standards}

\section{Acknowledgments}

The authors wish to thank the laboratory staff in different facilities where this study was conducted.

\section{Disclosure of conflict of interest}

The authors declare that they have no conflict of interest.

\section{References}

[1] World Health Organization. (2004). Medicinal plants - guidelines to promote patient safety and plant conservation for a U\$ 60 billion industry.

[2] Ernst E. (2005). The efficacy of herbal medicine: An overview. Fundam Clin Pharmacol, 19(4), 405-09.

[3] Aiyeloja AA and Bello OA. (2006). Ethnobotanical potentials of common herbs in Nigeria: A case study of Enugu state. Educational Research and Reviews, 1(1), 16-22.

[4] Oteng-Amoako AA. (2006). 100 tropical African timber trees from Ghana: tree description and wood identification with notes on distribution, ecology, silviculture, ethnobotany and wood uses. Candara and CG Omega, Ghana.

[5] Francois G, Diakanamwa C and Timperman G. (1998). Antimalaria and cytotoxic potential of four quassinoids from Hannoa chlorantha and Hannoa kleineana and their structure activity relationships. International Journal for parasitology, 28(4), 635-40.

[6] Ajaegbu EE, Younossa L, Danga Yinyang PS, Uzochukwu CI and Okoye Festus BC. (2016). Mosquito repellent activity of Spondias mombin L. (Family Anacardiaceae) crude methanol extract and fractions against Aedes aegypti (L.). IJNPR, 7(3), 240-44.

[7] Trease GE and Evans WC. (1989). Pharmacognosy, 13th Edition. Baillere Tindall, London, 39-250.

[8] Edeoga HO, Okwu DE and Mbaebie BO. (2005). Phytochemical Constituents of some Nigerian Medicinal Plants. African Journal of Biotechnology, 4(7), 685-88.

[9] Harborne JB. (1973). Phytochemical methods. A guide to Modern Technique of Plant Analysis. Chapman and Hall, LTD. London, 1-389. 
[10] Boham BA and Kocipai-Abyazan R. (1974). Flavonoids and Condensed tannins from leaves of Hawaiian V. aticulatum and V. calycinium. Pacific Science, 48, 458 - 63.

[11] Obdoni BO and Ochuko PO. (2008). Phytochemical studies and comparative efficacy of crude extracts of some homostatic plants in Edo and Delta States of Nigeria. Global Journal of Pure Applied Sciences, 203 - 208.

[12] Anchama C, Aphiwat T and Nuansiri R. (2005). Screening of antioxidant activity and antioxidant compounds of some edible plants of Thailand. Food Chemistry, 93, $491-497$.

[13] Okeke MI, Iroegbu CU, Eze EN, Okoli AS and Esimone CO. (2001). Evaluation of extracts of the root of Landolphiaowerrience for antibacterial activity. J Ethnopharmacol, 78, 119-127.

[14] Odeghe OB, Monanu MO and Anacletus FC. (2016). Phytochemistry of Achomanes Difformis Stem, Dioscorea Bulbifera Stem Bark, Fadogia Cienkowskii Leaf, Hannoa Klaineana Stem and Vitex Simplicifolia Leaf. Advances in Multidiscipline and Scientific Research, 2(1).

[15] Danijela P, Barbara S, Ivana S, Slavica D, Josipa B, Gordana R, Katlego E and Jacobus N. Phenolic Composition of Leaf extracts of Ailanthus altissima (Simaroubaceae) with Antibacterial and Antifungal Activity Equivalent to Standard Antibiotic. Natural Product Communications, 12(10), 1609 -12.

[16] Ajaiyeoba EO and Krebs HC. (2003). Antibacteria and antifungal activities of Quassia undulate and Quassia amara extracts in vitro. African Journal of Medicine and Medical Sciences, 32(4), 353-56.

\section{How to cite this article}

Ibe I, Ajaegbu EE, Ikuesan AJ, Dieke AJ and Ezugwu OC. (2020). Antimicrobial screening of the crude extract of Hannoa klaineana against some pathogens. GSC Biological and Pharmaceutical Sciences, 12(1), 249-254. 